\title{
Assessing the 2004 Campaign Websites: The Role OF THE INTERNET in Elections and Civil Society
}

\section{By Kenneth S. Coggeshall, Alexandra Michael, Shweta Bhatnagar, and Patricia D. Moynihan}

Abstract: The Internet is changing the face of political campaigns in the United States; not since the introduction of television have the tools used to communicate with the electorate changed so notably. This study uses the 2004 campaign websites created by the Democratic primary candidates and President George W. Bush to evaluate both the ways in which websites can help voters participate in democratic decisionmaking, and the ways in which websites may help candidates gain public support. We find that, given a list of 41 criteria deemed important to an informative, participatory and easy to use website, the average candidate's site earned just over half the possible points. Still, initial correlation analyses suggest that better websites may mean more votes on Election Day.

Information technology has changed the face of political campaigns in the United States. New devices, such as palm pilots, are being used for door-to-door campaigning; new software programs have been created for targeting specific voters; and candidates have used the Internet to facilitate their voter outreach initiatives. Indeed, not since 1952, with the introduction of the television in presidential campaigns, have methods to communicate with the electorate changed so notably. One of the most widespread applications of information technology by political candidates is the development of individual campaign websites.

The purpose of this study is to evaluate both the ways in which campaign websites can help voters participate more fully in democratic decision-making and, in turn, the ways in which these websites may help

Kenneth S. Coggeshall is a development officer at the National Democratic Institute for International Affairs. He has a Masters of Public Administration from The George Washington University with a concentration in nonprofit management. Prior to his post-graduate work, Ken was a social worker for a community mental health center, a quality assurance coordinator for a Medicaid home-health care program, and a musician. He has a Bachelor of Science in psychology from Wright State University where he researched human anxiety and its relation to situational factors and personality characteristics. candidates gain public support. By understanding the website features that promote participation in political discussions and help citizens understand the candidates' positions, we can better understand the role of the Internet in civil society. Further, by measuring the relationship between website quality and public support-using the percentage of the vote received and campaign donations as measures of public support-this research takes the first step toward understanding this tool's ability to help candidates win elections and may also suggest advancements or improvements to be made by candidates in the future.

\section{EMERGENCE OF THE INTERNET AS}

\section{a Campaign Tool}

Internet technology first received significant attention from political candidates during the 2000 presidential election when websites and other Internet-

Alexandra Michael is a 2004 graduate of the Master of Public Administration program at The George Washington University. She earned her bachelor's degree in English and dance from The George Washington University in 2002. Currently, she is a first-year law student at the Columbus School of Law at Catholic University. 
based technologies became common tools in both traditional and grassroots campaigning (Garrett 2004). These sites created an opportunity for candidates to disseminate information to thousands of people with the click of a button. Additionally, the sites opened the door for two-way, virtual communication. For example, Vice President Al Gore was one of the first political candidates to use an instant messaging service on his website to enable citizens to talk to one another about the presidential race and Vice President Gore's work (Davis et. al. 2002).

As the 2004 campaign cycle moved into full swing, the media displayed great interest in the Internet's use in the race for President. Howard Dean's campaign, the first to take advantage of <www.meetup.com>, a website that facilitated citizens coming together to organize and discuss political issues, candidates and campaigns, received extensive press coverage for its innovative strategies to engage citizens in the election process (Wolf 2004). Ultimately, each presidential candidate developed and maintained a website specifically dedicated to his or her campaign efforts and millions of voters logged on.

\section{Perspectives on the Effects}

\section{of Internet Technologies}

For much of this country's history, civic participation in public debate was conducted in faceto-face forums like town hall meetings and public rallies. The introduction of radio and, later, television

Shweta Bhatnagar is currently an assistant management analyst with the Las Vegas Valley Water District (LVVWD) in Las Vegas, NV. Her responsibilities include government affairs, research, and lobbying functions pertaining to water policies. She received a Master of Public Administration degree from The George Washington University in 2004, with a field concentration in intergovernmental relations, and a Bachelor of Arts in political science from the University of Nevada, Las Vegas in 1998. Prior to her position with LVVWD, Shweta worked for congressional and state government offices anda nonprofit organization dealing with food science and nutritional policies. put civic participation at a remove from the events of the day; the public got to know President Roosevelt over the radio and President Eisenhower over television. Use of the Internet in political campaigns puts the public at an even greater remove from candidates. Accordingly, arguments can be made both for and against technological advancements in the realm of public activism. Some feel that the increasing use of the Internet could weaken citizen participation and civic engagement among Americans while others view the Internet as a promising new medium that will enhance citizen involvement in the political processes.

Critics of the wide-spread use of the Internet in politics articulate three primary concerns regarding its use as a political tool:

a) the Internet creates information overload, effectively limiting a citizens' ability to distinguish between what information is credible and what is not;

b) Internet use does not foster or encourage civic engagement or citizen participation; rather, it further distances Americans from one another and from the democratic process; and

c) the Internet does not effectively address many of the real weaknesses of the American political system.

By the year 2000, there were nearly two billion websites accessible via the Internet (Campbell 2000). Recent estimates suggest that there may now be as

Patricia D. Moynihan is a 2004 graduate of the Master of Public Administration program at The George Washington University. She earned her Bachelor of Science degree in human services with minors in business administration and political science from Northeastern University in 1999. Currently, she is employed by the U.S. Department of Agriculture as a legislative analyst for food safety issues.

The authors would like to thank Kristen J. Pesicek for her technical assistance in preparing the data for this article. 
many as 17 billion web pages in use today with up to 10,000 pages being added daily (Metamend.com 2005). This massive proliferation of Internet content by corporations, advertisers, nonprofits, media outlets, retailers, entertainers, medical organizations, and political groups creates the distinct danger of "sweeping information overkill," (Whillock 1997). Perhaps more importantly, the amount of content on the Internet is so enormous that users often have trouble making their way through the vast sea of data to find information that is relevant and credible.

In addition to overwhelming people with the sheer volume of information, Internet technology may also have an adverse effect on civic participation by isolating people from each other. $A$ healthy, active public sphere is typically established and maintained by people who come together to form associations or participate in cooperative networks. These human mechanisms make the economy efficient, introduce citizens to politics, connect citizens to one another, and increase the level of knowledge about public issues; technology, on the other hand, not only inhibits these conditions but could be downright detrimental to them by separating people from each other (Putnam 2000). In order to hear a candidate's stance on an issue, people no longer need to attend rallies or debates, contact someone from the campaign office, or even talk to fellow citizens. Instead, individual voters can simply listen to a debate on the computer or read the transcript online. Campaign events that used to bring out thousands of people have been replaced by individual encounters with a computer.

Some critics focus not on the potentially damaging effects of the Internet but instead on its inability to address the real problems facing our political system. These authors argue that one of the major problems with the use of the Internet in the electoral process is that the technology does little to remedy the current problems associated with political campaigns, such as candidates presenting one-sided arguments and running commercials containing explicit ad bominem attacks (Whillock 1997). These authors acknowledge that the Internet may be a useful political tool but they are wary of placing too much emphasis on this new technology as the only tool for increasing citizen participation (Howes 2002). In order for the Internet to foster active participation on the part of voters,
Howes argues that political leaders may need to use the Internet in ways that elicit and incorporate public opinions into the discussions and actions of local decision-making bodies (2002). Unless those voices are given a genuine role in the process, the Internet may serve simply as an inactive suggestion box or complaint form rather than a forum for meaningful discussion.

While many of these concerns are valid, we believe that the Internet, and candidate websites specifically, have great potential to enable and encourage voter participation. Rather than being a unidirectional mode of information disbursement like traditional media, the Internet allows an interactive forum for exchanging ideas. Users are potentially able to engage in a discourse instead of passively absorbing information. Users also can organize as the grassroots level through the Internet by participating in web logs and online chat rooms and even arranging meetings outside the confines of cyberspace in "real time" (Brainard 2003). Some authors have found that such uses of technology may actually be a new form of creating communities comprised of people who would not have such a chance to interact without the broad reach of the Internet (Iozzi and Bennett 2003).

The use of the Internet offers advantages to candidates as well. Websites require very little effort and staff time to develop and maintain. A webmaster can easily post information or send e-mails to thousands of people within minutes. Websites can be changed, even several times a day, and can therefore provide citizens with the most up-to-the-minute information regarding candidates and campaign events. Additionally, websites greatly enhance the ease and speed with which citizens can make monetary donations to a campaign, a significant advantage for candidates because they do not have to rely as heavily on the traditional time- and labor-intensive methods of raising money.

The use of the Internet in political campaign carries both costs and benefits. Ultimately, the best way to use the Internet is to recognize both its strengths and its weaknesses and consider them carefully as its uses expand and evolve in the future. 


\section{A STUdy OF THE INTERNET'S UsE}

\section{IN THE 2004 ELECTION}

This study examines the manner in which the 2004 election websites facilitated citizen education and engagement in the political process and how the quality of the websites related to levels of public support received by the candidates. To do this, we collected data from the presidential candidates' websites, including those of George W. Bush, Wesley Clark, Howard Dean, John Edwards, Dick Gephardt, John Kerry, Dennis Kucinich, Lyndon LaRouche, Carol Moseley Braun, Ralph Nader, and Al Sharpton. ${ }^{1}$ Joe Lieberman was excluded from the analysis because he dropped out of the presidential race after the Iowa caucus and the campaign dismantled his website before we had the opportunity to complete our evaluation.

In the first phase of the analysis, we sought to evaluate how the candidates' websites reached voters, what information they provided and if they allowed citizens to interact with each other, the candidate's staff and the candidate. To do this we evaluated each site based on a total of 41 criteria grouped into three categories: Ease of Use, Information, and Interaction. Our evaluation criteria were partially drawn from Click on Democracy by Davis, Elin and Reeher (2002), which studied the effectiveness and influence of campaign websites during the 2000 presidential election. In examining the 2004 websites, we supplemented Davis, Elin and Reeher's evaluation methods with criteria set forth in two reports by Darr and Graf (2004) at the Institute for Politics, Democracy and the Internet at The George Washington University, Pioneers in Online Politics: Nonpartisan Political Web Sites in the 2000 Campaign and Nonpartisan Political WVeb Sites: Best Practices Primer. We measured features including the presence of search engines, links to other sites, and the availability of two-way communication. The sites were examined during the early stages of the 2004 primary season (January-February) before the Iowa caucuses and New Hampshire Democratic primary. The websites were then checked weekly to see if any changes had been made. While we noted the website changes and updates, our data were compiled on the basis of what actually appeared on each site before the first caucus and primary race in 2004. We continued surveying the websites until the beginning of May 2004.

\section{Criteria Used for Website}

\section{Evaluation}

The criteria selected for the Ease of Use category evaluated features on a website that make it easy for a user to navigate. These features include availability of Portable Document Format (PDF) versions of documents and links to Adobe downloads to allow users to view PDF files, search functions that allow the user to search the site for specific material, textonly options to enable printing of material, technical assistance, privacy statements to ensure security while on the site, and Spanish text options. We also checked the site for working links and hyperlinks to search important keywords. The presence of non-campaign related pop-ups are also included criteria. In all, the Ease of Use category included ten individual factors.

The second broad category, Information, focused on different types of information on the website. Criteria in this category were inclusion of a calendar or an event schedule, issue-related position statements, the candidate's biography, voting record, and the candidate's position on issues compared with his or her rivals' positions. Also included were availability of previous speeches in audio/video form, links to state and/or local area political events, fundraising updates, a list of endorsements, archived press releases, current events relating to the campaign, and polling results. Finally, we examined how many different forms of contact information were provided, including mailing address, telephone and fax numbers and e-mail addresses.

The third category we examined was Interaction. In this category, we examined website features that promote civic participation. We looked at citizen-tocampaign interaction, which includes the ability to sign up for campaign newsletters or e-mail updates, register to vote, sign up to be a campaign volunteer or a volunteer for a specific event, participate in online polls that suggest how the candidate should stand on an issue or purchase campaign material, ways to make online monetary contributions and/or how to mail financial contributions to the campaign. We also 
reviewed features that allowed citizens to communicate with the campaign staff through web logs, Internet chat groups and bulletin boards. Finally, we checked to see if the website provided the user with the means to ask the candidate a question via e-mail. Moteover, we e-mailed each of the candidates and recorded whether a response was received.

Under citizen-to-citizen interaction, the factors examined were presence of web logs, online chat groups, and Internet bulletin boards by which a voter could talk to other voters. Also included as an evaluation criterion was the presence of a link to a general website such as <www.meetup.com> where citizens could communicate with each other about current political issues and concerns. A complete list of evaluation criteria can be found in Appendix A.

For each feature present on a particular website, a score of 1 was given for that criterion. Websites lacking a given criterion were assigned a 0 for that particular criterion. For example, a website that included a candidate's voting history was given a 1 for that criterion but a 0 if no voting history appeared. However, some criteria had to be quantified differently. First, each website was given one point if it contained three or more ways to contact the campaign; otherwise the website received a 0 for the contact information criterion. Second, if pop-up windows unrelated to the campaign-which might be expected to deter useappeared on the website, a score of 0 was given for this feature. Each website was also given a composite score that combined the totals in all three categories. ${ }^{2}$

In the second phase of the analysis, we took the candidates' scores and, using a Pearson's correlation, measured the relationship between website quality and candidate support. Support is defined using the following factors:

1) Percentage of vote receive in the 2004 Iowa Caucus

2) Percentage of the vote received in the 2004 New Hampshire Democratic primary

3) Total donations received in the $4^{\text {th }}$ quarter of 2003
We chose these measures both because these are the outcomes that candidates ultimately care about and because data on these activities are generally accessible, accurate and reliable. President Bush was not included in the correlation analysis. As an incumbent president, running virtually unopposed, Bush was a statistical outlier and may have had an undue impact on the results as a whole. There were a maximum of 10 observations in the correlation analysis. ${ }^{3}$

Data for this phrase were drawn from two sources. Vote percentages received in the Iowa caucus and $\mathrm{New}$ Hampshire primary were found on an Internet-based news source, CNN (2004). Fundraising information was based on teports from the Federal Elections Commission (2004).

\section{FINDINGS}

This section presents the findings from the content and correlation analyses. The first four graphs show each website's composite score (Fig.1) and the scores for the three component categories (Figs. 2-4). 
Figure 1: Composite Website Scores

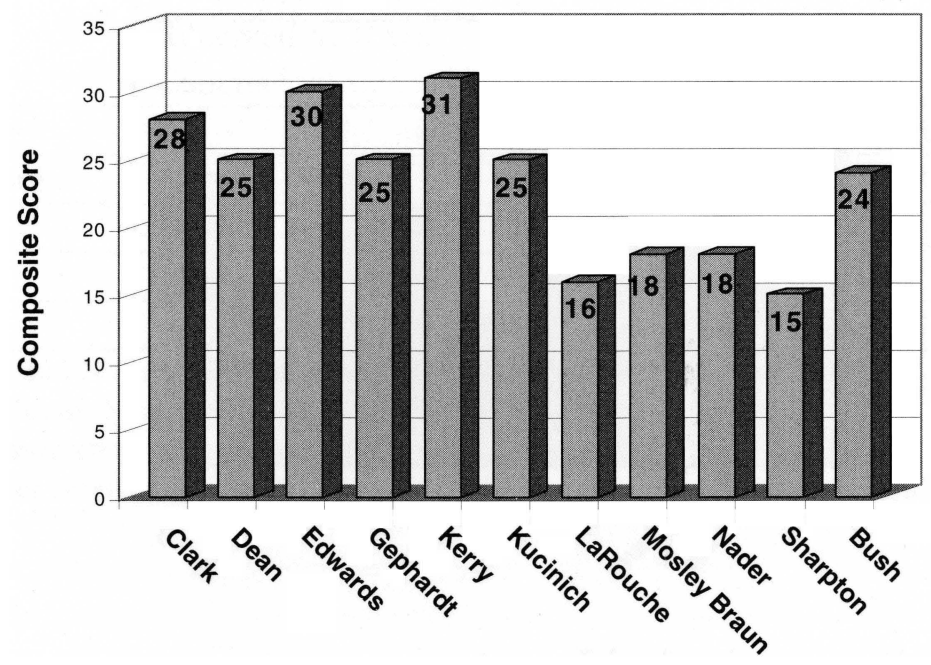

Despite the Internet's potential as a tool to enhance our democracy, overall the quality of the 2004 campaign websites in the study was mediocre. The typical (median) candidate's site scored 25 out of 41 possible points. The mean score was slightly lower at
23 points, indicating the average campaign site had just over half the features of a high-quality site. Some candidate's websites scored better than others. Individual scores ranged from 31 for Kerry to 15 for Sharpton.

Figure 2: Ease of Use Scores

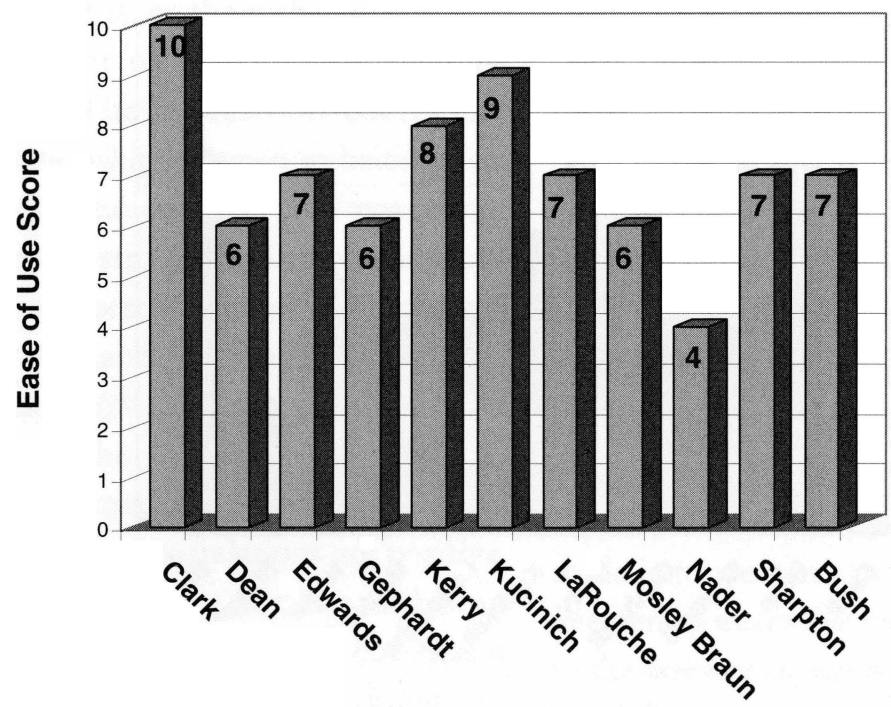

The ease with which citizens can access information is a basic but vital component of website quality. We considered 10 features when evaluating the sites' Ease of Use. On average, the candidates performed best in this category. Clark scored a perfect 10 , making him the only candidate to earn all possible points in a category. Nader ranked the lowest with a score of four. While there was a relatively broad range of scores in this category, most candidates scored near the high end-seven was both the mean and median website score in this category. 
Figure 3: Information Scores

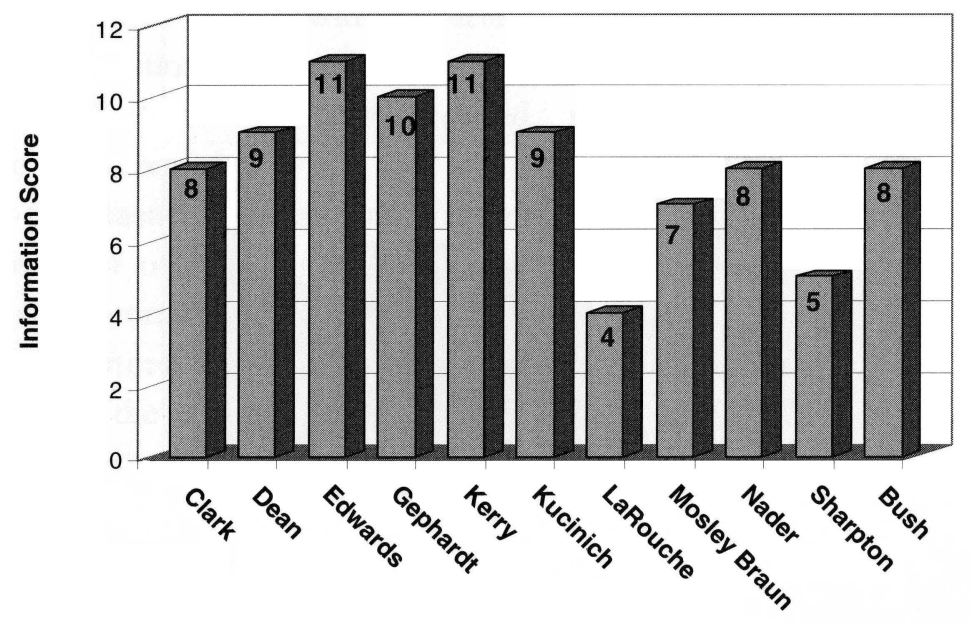

The highest possible score in the Information category was 14. The top scorers were Kerry and Edwards, who tied at 11. LaRouche and Sharpton received the lowest scores, a four and five respectively. ${ }^{4}$ On average, the candidates included slightly over half of the features considered important to their efforts to inform citizens of their political views (mean and median $=8$ ). The candidates were most likely to document their individual positions on various political and social issues on their sites while they were least likely to report actual voting records. ${ }^{5}$

Figure 4: Interaction Scores

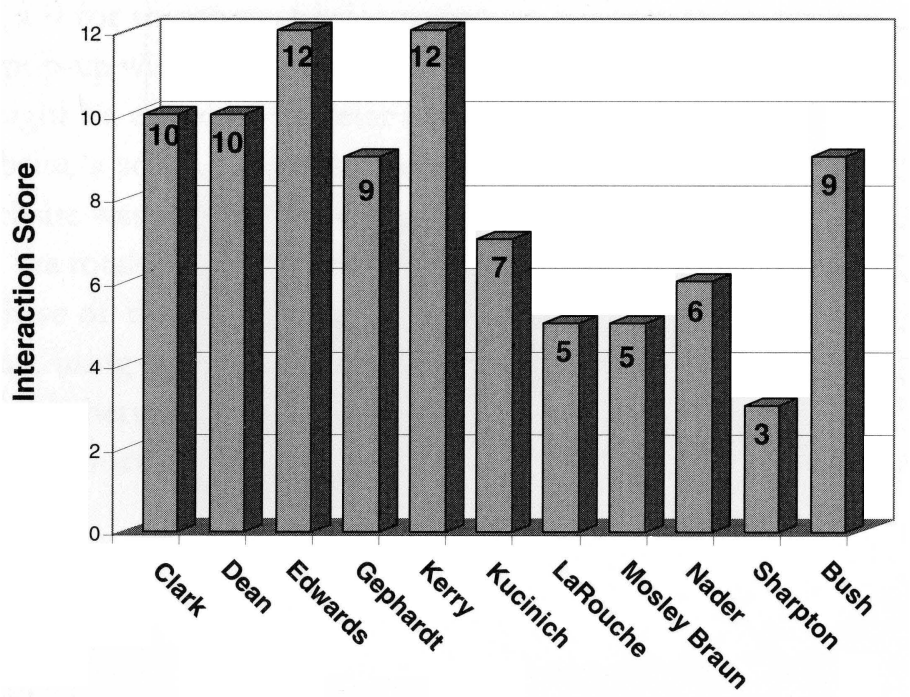

Interaction was the only category for which both the mean and the median scores fell below the midpoint of total possible points; in other words, the typical candidate's site had less than half of the features we consider important to promoting citizen participation. The highest possible score for Interaction was 17 and both the mean and median scores were eight. The scores ranged from three to
12 with Kerry and Edwards tied for first and Sharpton's site coming in last. The websites were most likely to contain features that allowed the user to make online contributions or features that solicited campaign volunteers. The most infrequently found feature was the presence of online bulletin boards that would allow either users or campaign staff to post notices or comments. 
Table 1: Relationship Between Website Criteria Scores and Public Support

\begin{tabular}{|l|c|l|l|}
\hline & $\begin{array}{l}\text { Percent of Vote } \\
\text { Received in Iowa } \\
\text { Caucus* }\end{array}$ & $\begin{array}{l}\text { Percent of Vote } \\
\text { Received in New } \\
\text { Hampshire Primary** }\end{array}$ & $\begin{array}{l}\text { Amount of } \\
\text { Donations Received } \\
\text { (in millions)*** }\end{array}$ \\
\hline Website Score & \multicolumn{3}{|c|}{ Correlation Coefficient } \\
\hline Composite Score & .87 & .69 & .63 \\
\hline Ease of Use & .10 & -.11 & .02 \\
\hline Information & .79 & .67 & .53 \\
\hline Interaction & .92 & .77 & .73 \\
\hline
\end{tabular}

*Candidates Clark and Nader did not participate in the Iowa caucuses.

**Candidates Gephardt, Mosely-Braun and Nader did not participate in the New

Hampshire Democratic primary.

****Candidate Nader received no reportable contributions during the period examined.

Taken together, this evaluation suggest that candidates are doing a relatively better job at making their websites easy to use and informative than they are at using them to engage voters in political dialogue.

Table 1 reports the correlation coefficients between the composite and three component website scotes and the three measures of public support. In each of the composite score relationships, there is a positive correlation. That is, as the website scores go up, so does the amount of support received by individual candidates. The correlation coefficient indicates a strong relationship between website scores and percentage of the vote received in the Iowa caucus $(r=87)$ and a moderately strong telationship between website scores and both percentage of votes received in the primaries $(r=.69)$ and the amount of money received in contributions ( $r=.63$ ).

When examining the relationships between components of website quality and public support, we find that eight of the nine correlations are positive. The strongest relationships are for the websites' Interaction scores. In fact, the notably high coefficient of .73-associated with the amount of donations received by a candidate-indicates the weakest of the Interaction relationships. The correlation coefficients for Information scores and public support are also noticeably high with amount of donations producing the weakest of the Information relationships ( $r=.53$ ). The weakest positive correlation $(r=10)$ and the only negative correlation ( $r=-.11)$ were both in the Ease of Use category.

\section{Limitations to the Analysis}

One limitation to the website evaluation in this study relates to the criteria chosen as indicators of website quality. While the criteria used here are based on past research in the field, it is possible that there are other, less tangible or immediately relevant characteristics of websites that we did not consider. For example, some websites may have had a better color scheme, more photogtaphs of the candidate, better menu placement or faster download times for various features, all of which individual users may consider relevant to quality.

Another limitation is the time lag between the measure of campaign donations and the point at which the website data were captured. Website data were recorded during late January and early February 2004. Donation data were gathered from FEC submissions covering the period October 1, 2003, through December 31, 2003, as this was the most recent time period for which fundraising data were available. It is possible that the campaigns made improvements or changes to their websites in the intervening weeks that might have contributed significantly to the amount of funds they were able to raise.

With regard to the correlation analysis, it is important to remember that the presence of a positive correlation between website scores and electoral support measures does not mean that better websites cause an increase in voter support. In fact, the reverse may be true. That is, candidates with higher levels of support may have more tesources that enable them to develop better websites. Additionally, the relationship may be spurious, meaning that another variable is 
influencing both website quality and votes or donations. However, the fact that these correlations were positive across many website criteria and citizen support measures suggests that there may be a relationship between the use of the Internet by political candidates and number of votes for the candidate. Understanding the nature and direction of this relationship should be among the goals of future research in this area.

\section{Discussion}

Our research shows that many political candidates are using the Internet as a campaign tool. Each candidate in the 2004 election had a campaign website and all of them were reasonably advanced. These websites included features that promote citizen involvement in the political process both through information about the candidates and forums for interaction with other citizens. But overall, the quality of the 2004 presidential campaign websites was mediocre; the sites included just over half of the features traditionally considered helpful in informing and involving citizens.

Promoting citizen-to-citizen and citizen-tocandidate dialogue is the area of the campaign websites that need the most improvement. In 2004, they failed to capitalize on these more dynamic web-based elements. While Al Gore in 2000 and Howard Dean in 2004 both were able to demonstrate the power of the Internet as an interactive tool, its potential has yet to be widely tapped into in mainstream politics. Features such as <www.meetup.com> or web logs were sparse and instant messaging services were not used by any candidate in 2004.

A website visitor's ability to interact with the candidates was further hindered by the websites' topdown approach to information-sharing. In this study, we found that neither the candidate or nor campaign staff responded to messages sent via the website or they simply responded with "canned" e-mail. A visitor could get a candidate's contact information from the website but the information is of little value if the candidate does not tespond to e-mail. This is a situation that does not appear to have improved much since researchers evaluated the 2000 presidential campaign websites (Davis et al. 2002).
The top-down flow of information means candidates were more likely to post information on their candidacy on their websites than to actively use the sites to promote participation. Indeed, the fact that nearly all campaign sites contained policy position statements suggests that websites may be emerging as a reasonable alternative source of information in elections. This is an important finding because some studies have shown that the mainstream media tend to focus on superficial issues that arise in political campaigns (Media for Democracy 2004). Further research is needed to determine whether websites provide more substantive information than other sources regarding the candidates and policy issues.

The average website in this study earned the most possible points for the ease with which a person could navigate the site. Interestingly, our research found that a website's relative ease of use is the only measure of quality that does not relate to whether people are willing to vote for or donate to a given candidate, as shown by the correlation analysis. While the limitations to this methodology have been stated, we do believe that these findings provide strong support for further research into the relationship between Internet technologies and political participation.

While we believe that our findings highlight the potential of the Internet as a political tool, we also recognize the various bartiers that may limit its effectiveness. First, there are still a large number of people who do not have regular access to the Internet. Studies have shown that Black and Hispanic households have lower rates of Internet access at home than White or Asian households and lower socioeconomic status is also related to lower rates of Internet access at home (U.S. Department of Commerce 2002). Though a seemingly obvious point; candidate websites are largely irrelevant to individuals who do not have access to the Internet in the first place. As a result, some authors have called for government action to ensure that every citizen has access to the Internet (Davis et al. 2002).

Additionally, it is unclear that even those people who have access to the Internet will use it to participate in the political process. For example, the Department of Commetce has documented the variation in Internet by age. Older people are more likely to use the Internet for e-mailing rather than for participating in online 
chat groups and list serves. As the costs of computer hardware and Internet service decline and the practices of individuals using the Internet change, this "digital divide" may narrow, but even if universal access were achieved we do not know whether the public will actually visit campaign websites in appreciable numbers. Motivating the public to use the Internet to research political candidates and campaigns could, in fact, be a bigger challenge than the issue of equal access.

\section{Conclusion}

Technology is a major force in economics, politics and public policy (Brainard 20013). Creating new ways for technology to reach and truly interact with citizens, fulfill their wants and needs, and allow them to participate more fully in the public arena will be critical in the years to come.

The potential benefits of extending Internet technology to political campaigns are clear: increased sharing of information, heightened participation, stronger volunteer efforts and perhaps even changes in political attitudes. If we can continue to improve our ability to capture these benefits effectively, the Internet promises to give people a way to engage in the community of politics-and the politics of community - in ways that are faster, easier, and more effective than ever before (Wellman 2002; Haythornwaite and Wellman 2002).

\section{Notes}

'Website citations can be found in the References section of this article.

${ }^{2}$ Our group convened on a weekly basis to discuss our findings and to guard against any individual interpretation of data that might compromise the reliability of our research. We each took personal notes on our assigned websites and then discussed any unclear criterion that was observed. As a group we then decided if the site would receive a 1 or if it failed to meet our standards and receive a 0 . A few times our group collectively viewed the websites in order to make a unanimous decision about how to score a certain element.

${ }^{3}$ Please refer to Table 1 for more details on the observations included in the correlation analysis.

"It is interesting to note that the results in this category generally mirror the overall results, with Kerry and Edwards also receiving the highest overall scores and LaRouche and Sharpon also receiving the lowest overall scores.

"Clearly, this statement applies only to candidates who had held public office prior to entering this race.

\section{REFERENCES}

Al Sharpton for President. 2004. http://www. alsharpton2004.org.

Bollier, David. 2001. Public assets, private profits: Reclaiming the American Commons in an age of market enclosure. Washington, D.C.: New America Foundation.

Brainard, Lori. and Patricia D. Siplon. 2002. Cyberspace challenges to mainstream nonprofit health organizations. Administration and Snciety. 34: 141175.

Brainard, Lori. 2003. Citizen organizing in cyberspace: Illustrations from health care and implications for public administration. American Review of P'ublic Administration. 33 (4): 384-406.

Campbell, K. K. 2000. Click through the clutter. Profit. http://www.profitguide.com/magazine/ article.jsp? content $=250$.

Carol Mosley Braun for President. 2004. http:// www.carolforpresident.com.

Clift, Steven. 1998. Democracy is online. Internet Society. March/April, http://www.publicus.net/articles/ democracyisonline.html.

- 2000. Top ten L-Dentoracy "To Do L ist" for governments around the world. Publicusnet. http://www. publicus.net/articles/egenten.hmm. 
CNN. 2004. Primary results Nem Hampshire: Jantary 27. http://www.cnn.com/ELECTION/2004/ primaries/pages/states/NH/.

- 2004. Sbowdown Iowa. Accessed at http:// www.cnn.com/ELECTION/2004/special/ president/showdown/IA/.

Cornfield, Michael. 2003. Dean's List. Campaigns \& elections. $24: 8$.

Darr, Carol C. and Joseph Graf. 2004. Pioneers in online palitics: Nonpartisan political web sites in the 2000 campaign. Institute for Political Democracy \& the Internet. http://www.ipdi.org/UploadFiles/ IPDI_Pioneers_in_Online_Politics.pdf

-. 2004. Political influentials online in the 2004 presidential campaign. Institute for Political Democracy \& the Internet. http://www.ipdi.org/Influentials/ Report.pdf.

\section{- 2004. Nonpartisan political web sites: Best} practices primer. Institute for Political Democracy \& the Internet. http://www.ipdi.org/UploadedFiles/ nonpartisan_primet.pdf.

Davis, Steve, Larry Elin, and Grant Reeher. 2002. Click on democracy. Cambridge, MA: West View Publishing.

Dennis Kucinich for President. 2004. http://www. denniskucinich.us.

Dick Gephardt for President. 2004, http://www. dickgephardt2004.com.

Federal Election Commission. 2004. Presidential prenomination campaign receipts through March 31. http:// www.fec.gov/press/bkgnd/pres_cf/atm03312004/ presreceiptsm42004.pdf.

-2004. Presidential pre-nomination disbursements March 31, 2004. http://www.fec.gov/press/bkgnd/ pres_cf/atm03312004/presdisbursem42004.pdf

Garrett, Jesse J. 2004. User experience analysis: Presidential campaign sites. Adaptive Path Reports. http://www.adaptivepath.com.

George W. Bush for President. 2004. http://www. georgewbush.com.
Graber, Doris. 2001. Adapting political news to the needs of twenty-first century Americans. In Mediated politics: communication in the future of democracy. Edited by W. Lance Bennett \& Robert M. Entman. Cambridge: Cambridge University Press.

Halstead, 'Ted. 1999. Politics for Generation X: Today's young adults may be the most politically disengaged in American history. The Atlantic Monthly. August.

Hatfield, Dale. 2001. A look at the promise and policy implications of new wireless technologies. Address at the Ford Foundation Digital Media Forum. Alexandria, VA. May 30.

Haythornwaite, Caroline and Barry Wellman. 2002. The Internet in everyday life. Oxford, UK: Blackwell. 3-44.

Howard Dean for President. 2004. http://www. deanforamerica.com.

Howes, Michael. 2002. Reflexive modernization, the Internet, and democratic envitonmental decision making. Organization and Environment. 15: 328-333.

Iozzi, David and Lance Bennett. 2003. Crossing the campaign divide: Dean cbanges the election game. Center for Communication \& Civic Engagement. University of Washington. http://depts.washington.edu/ccce/ assets/documents/iozzi_bennet_crossing.pdf.

Jackson, Nigel. 2003. MPs and web technologies: An untapped opportunity? Journal of Public Affairs. 3:2.

Jobn Edwards for President. 2004. http://www. johnedwards2004.com.

Jobn Kerry for President. 2004. http://www. johnkerry.com.

Kaid, Lynda L. 2002. Political advertising and information seeking: Comparing exposure via traditional and Internet channels. Journal of Advertising. 31:1.

Klein, Alec. 2001. For AOL and Microsoft, it's hightech noon. Washington Post. June 8.

Kraut, Robert, Michael Patterson, Vicki Lundmark, Sara Kiesler, Tridas Mukopadhyay, and William Scherlis. 1998. A social technology that reduces social involvement and psychological well-being? American Psychologist. 53 (9): 1017-31. 
Levine, Peter. 2000. The neis Progressive Era: Toward a fair and deliberative democracy. Lanham, MD: Rowman and Littlefield.

Lyndon LaRoucbe for President 2004. http://www. larouchein2004.net.

Mann, Sheilah, 1999. What the Survey of American College Freshmen tells us about their interest in politics and political science. PS: Political Science of Politics. 32 (2): 263-268. June 1.

May, Vaughn. 2000. Politics, internet assignments, and civic knowledge. College Teaching. 48 (2): 43-47.

Media for Democracy. 2004. Take action! 'Horse Race' tramples the issues. http://www.mfd2004.us/ campaign/networknotice/.

Metamend.com. How big is the Internet? http://www.metamend.com/internet-growth.html.

Putnam, Robert. 2000. Bowling alone: The collapse and revival of American community. New York: Simon \& Schuster.

Ralph Nader for President. 2004. http://www. votenader.org.

Sparks, Colin. 2001. The Internet and the global public sphere. In Mediated politics: communication in the future of democracy. Edited by W.L. Bennett \& R.M. Entman. Cambridge: Cambridge University Press.

Stromer-Galley, Jennifer. 2000. On-line interaction and why candidates avoid it. Journal of Communication. 50: 111-132.

Wellman, Barry. 2001. Computer networks as social networks. Science. 293: 2031-2034.

U.S. Department of Commerce. 2002. A nation online: How Americans are expanding their use of the Internet.

Wesley Clark for President. 2004. http://www. clark04.com.

Wilkins, Karin G. 2000. The role of media in public disengagement from political life. Journal of Broadcasting and Electronic Media. 44 (4): 569-580.

Whillock, Rita K. 1997. Cyber politics: The online strategies of '96. American Bebavioral Scientist. 40 (8): 1208-1225.

Wolf, Gary. 2004. How the Internet invented Howard Dean. Wired News. http://www.wired.com/wired/ archive/12.01/dean_pr.html. 


\section{Appendix A: Evaluation Criteria}

\begin{tabular}{|c|c|c|c|}
\hline Ease of Use & Information & \multicolumn{2}{|c|}{ Interaction } \\
\hline & & Citizen-to-Citizen & $\begin{array}{l}\text { Citizen-to- } \\
\text { Campaign }\end{array}$ \\
\hline $\begin{array}{l}\text { PDF versions of } \\
\text { documents }\end{array}$ & Calendar/event schedule & Web log & $\begin{array}{l}\text { Online contributions } \\
\text { (can send \$ online) }\end{array}$ \\
\hline Search functions & Position statements & $\begin{array}{l}\text { Call to action (travel, } \\
\text { write letters, email, call) }\end{array}$ & $\begin{array}{l}\text { Mail only } \\
\text { contributions (must } \\
\text { mail in \$) }\end{array}$ \\
\hline Text-only option & Biography & Chat groups & $\begin{array}{l}\text { Online volunteer } \\
\text { signups }\end{array}$ \\
\hline Technical help & Voting rccord & Bulletin boards & $\begin{array}{l}\text { E-mail } \\
\text { updates/newsletters }\end{array}$ \\
\hline $\begin{array}{l}\text { Links to adobe } \\
\text { download }\end{array}$ & Speeches, audio/video clips & $\begin{array}{l}\text { Links to meetup.com } \\
\text { or similar services }\end{array}$ & Register to vote \\
\hline Privacy statement & Links to related sites & & $\begin{array}{l}\text { Events } \\
\text { signup/volunteer to } \\
\text { organization }\end{array}$ \\
\hline Spanish option & $\begin{array}{l}\text { State/local specific web } \\
\text { pages }\end{array}$ & & $\begin{array}{l}\text { Response to inquiry } \\
\text { (stand on an issue, } \\
\text { questions) }\end{array}$ \\
\hline Working links & Polling results & & $\begin{array}{l}\text { Issue related poll } \\
\text { tesults (public votes if } \\
\text { candidate } \\
\text { should/shouldn't } \\
\text { support an issue) }\end{array}$ \\
\hline $\begin{array}{l}\text { Pop-ups not related to } \\
\text { the campaign }\end{array}$ & $\begin{array}{l}\text { Stance on issues compared } \\
\text { with other candidates }\end{array}$ & & $\begin{array}{l}\text { Purchase campaign } \\
\text { merchandise }\end{array}$ \\
\hline \multirow{5}{*}{$\begin{array}{l}\text { Hypetlinks to search } \\
\text { keywords }\end{array}$} & Fundraising updates & & Web log \\
\hline & List of endorsements & & Bulletin boards \\
\hline & Archived information & & Chat groups \\
\hline & Current events/In the News & & \\
\hline & $\begin{array}{l}\text { Contact information ( } 3 \text { or } \\
\text { more methods: email, phone, } \\
\text { address, fax, etc.) }\end{array}$ & & \\
\hline
\end{tabular}

